\title{
Meso- or xeromorphic? Foliar characters of Asteraceae in a xeric scrub of Mexico
}

\author{
Patricia Rivera ${ }^{1,2^{*}} \mathbb{0}$, José Luis Villaseñor ${ }^{1}$ and Teresa Terrazas ${ }^{1}$
}

\begin{abstract}
Background: The anatomical traits associated with water deficit are also observed in plants growing in poor soils. The species may resist water deficit through three main strategies: escape, avoid or tolerate. The Pedregal de San Ángel Ecological Reserve (REPSA), Mexico, is an environment with low nutrient soil and low water availability. It is set on the basalt formation derived from the Xitle volcano eruption. The main vegetation type is characterized as xerophytic shrub. Thus we expect that species growing in this community will show leaf xeromorphic traits and may have any of the three response strategies. We analyzed the foliar anatomy of 52 species of the Asteraceae family at the REPSA because it is the most abundant angiosperm family in the site, showing a wide variety of growth forms and anatomical variation.

Results: The foliar anatomies of the studied Asteraceae were highly variable as well as their quantitative traits as revealed by principal component analysis. This agrees with previous studies that found great anatomical variation within the family. Leaves have multiple layered palisade parenchyma and parenchyma bundle sheaths and could not be categorized as xeromorphic because they possess mesomorphic leaf features as simple lamina, single-layered epidermis, and soft large-size glabrous leaves with high specific leaf area.

Conclusions: The combination of mesomorphic and few xeromorphic foliar traits with other characters at the genus and tribal level probably has been essential in Asteraceae to colonize various environments, including those with low water and nutrient availability.
\end{abstract}

Keywords: Astereae, Eupatorieae, Heliantheae, Foliar anatomy, Poor soils, Water stress

\section{Background}

Plants growing under xeric conditions can have a set of anatomical, physiological or phenological adaptations allowing them to escape, avoid or tolerate water stress (Santos and Ochoa 1990; Fahn and Cutler 1992; Dickison 2000; Valladares et al. 2004). Drought-escaping species generally are annual or biannual herbs that develop their life-cycle in short time periods when conditions are favorable (Kramer 1983; Santos and Ochoa 1990; Fahn and Cutler 1992; Valladares et al. 2004) or they usually possess perennation structures, such as bulbs, rhizomes or runners that remain latent until conditions are favorable again. Plants showing the avoidance-of-stress

\footnotetext{
*Correspondence: rivera.perezpatricia@gmail.com

1 Departamento de Botánica, Instituto de Biología, Universidad Nacional Autónoma de México, Apartado Postal 70-367, 04510 Mexico City, Mexico Full list of author information is available at the end of the article
}

strategy possess some features enabling them to minimize or compensate for water loss or to increase water uptake and avoid desiccation. Indicator traits of the drought avoidance mechanism include deep roots, small or strongly lobulated leaves, mesophyll cells smaller in size, thick cell-walls and cuticles, multiseriate epidermis, strongly developed palisade parenchyma, stomata sunken or in crypts and abundant trichomes (Esau 1976; Kramer 1983; Santos and Ochoa 1990; Gibson 1996; Dickison 2000; Valladares et al. 2004; Fang and Xiong 2015). Drought tolerating plants can sustain a certain level of physiological activities under stress conditions. Tolerating plants show tissues resistant to dehydration and characters such as stress-induced leaf abscission, succulent leaves, lignified cell-walls, mucilage accumulation and the occurrence of buliform cells (Kramer 1983; Santos 
and Ochoa 1990; Dickison 2000; Valladares et al. 2004; Fang and Xiong 2015).

Traits of stress-avoiding and stress-tolerating plants have also been related to soil nutrient deficit (Dickison 2000; Fonseca et al. 2000; Wright et al. 2002). In fact, soil nutrient availability explains better the distribution of foliar characters in plants around the world than mean annual temperature, mean annual precipitation and irradiance together (Ordoñez et al. 2009). It has been hypothesized that xeromorphism has evolved from the adaptation of mesomorphic plants to low nutrient soil (Fahn and Cutler 1992) or to both, the lack of water and poor soils. These two conditions are found at the Pedregal de San Ángel Ecological Reserve in the Basin of Mexico.

The Pedregal de San Ángel Ecological Reserve (REPSA) is a protected area for the vegetation at the southern edge of the Mexico basin (Fig. 1a). The REPSA is located in the southwest region of the Mexico City basin $\left(19^{\circ} 18^{\prime} 21^{\prime \prime}\right.$ to $19^{\circ} 20^{\prime} 11^{\prime \prime} \mathrm{N}$ and $99^{\circ} 10^{\prime} 15^{\prime \prime}$ to $\left.99^{\circ} 12^{\prime} 4^{\prime \prime} \mathrm{W}\right)$, at an elevation interval of 2292-2365 m, and it encompasses an area of 237.3 ha (Fig. 1a). The vegetation type has been characterized as xerophilous scrub (Rzedowski 2006). This ecosystem is on a set of basaltic formations produced by the solidification of lava flow during the eruption of the Xitle volcano about 1670 years ago (Siebe 2000). Although mean annual precipitation is $883 \mathrm{~mm}$, the bedrock does not allow water retention and the soil is shallow. So aridity in this site is more edaphic than climatic. It is a unique system in the world because it is within the biogeographic province of the Transmexican Volcanic Belt (Morrone 2006) and the flora composition has Neotropical and Nearctic affinities (Rzedowski 1998; Rzedowski and Rzedowski 2005). The vegetation surrounding the REPSA includes various types of forests, including oak forest, fir forest, and cloud forest (Rzedowski and Rzedowski 2005; Lot and Cano-Santana 2009), which is consistent with the vegetation type expected given the elevation (over 2240 masl), the mean annual rainfall $(770-1200 \mathrm{~mm})$, and the mean temperature $\left(11-15{ }^{\circ} \mathrm{C}\right)$ of the site (Fig. 1b). Therefore, it is assumed that species hat colonized after the eruption came mainly from the surrounding forests; however, the current vegetation type is xerophilous scrub (Castillo-Argüero et al. 2007; Lot and Cano-Santana 2009). At the REPSA, the Asteraceae family shows the highest number of species compared to the 73 other vascular plant families found there (Castillo-Argüero

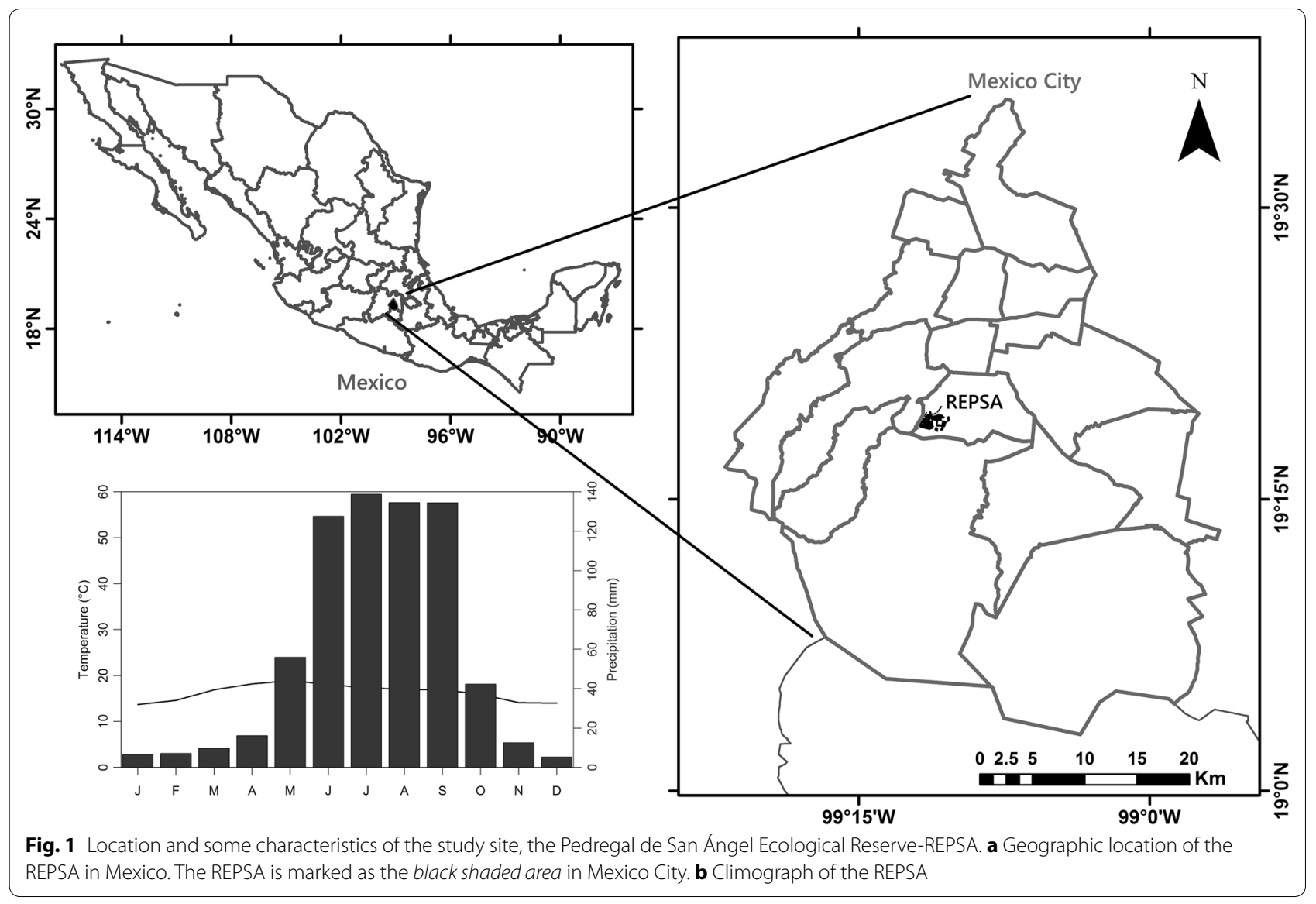


et al. 2004, 2007; Lot and Cano-Santana 2009). Céspedes (2010) reported 93 species belonging to 51 genera classified in 13 tribes of Asteraceae in this site. Moreover, the morphological diversity of the family is well represented, as there is a wide variety of growth forms, polyploid species and species with high chromosomic numbers (SotoTrejo et al. 2011).

The foliar anatomy of Asteraceae has been studied mainly in species with economical value (Ragonese 1988; Ferreira et al. 2002; Freire et al. 2005, 2007; Milán et al. 2006). The leaves are usually dorsiventral, hypo- or amphistomatic and have anomocytic stomata. However, it is difficult to assert generalizations regarding the foliar anatomy of Asteraceae because there is so much variation in characters such as stomata distribution, trichome density and type, hypodermis development, presence of secretory structures and parenchymatic vascular bundles sheaths (Anderson and Creech 1975; Metcalfe and Chalk 1979; Freire et al. 2005). The usefulness of foliar characters for taxonomic classification at the genus or species level (Ferreira and De Oliveira 1989; Castro et al. 1997; Luque et al. 1999; Delbón et al. 2007; Adedeji and Jewoola 2008) or for phylogenetic and ecological studies (Boeger and Wisniewski 2003; Horn et al. 2009) has been overlooked because most studies have focused exclusively on examining the epidermal surface (Ferreira et al. 2002; Freire et al. 2005, 2007; Adedeji and Jewoola 2008; Gil et al. 2012; Redonda-Martínez et al. 2016) and ecological or leaf evolution traits are missing for Asteraceae as they have been generated for other plant families (Luckow 2002; Schmerler et al. 2012; Brodribb et al. 2013).

We hypothesize that Asteraceae species at this ecological protected area (REPSA) will show anatomical traits for avoiding or tolerating stress, the aim of this study was to characterize the foliar anatomy of a sample of 52 species belonging to 41 genera and 13 tribes of Asteraceae living in the xeric environment of this reserve.

\section{Methods}

The present study was conducted in the REPSA, within the central campus of the National Autonomous University of Mexico (UNAM, Fig. 1a). Samples were collected during two rainy seasons from August 2008 to December 2009. Three to six fully developed leaves showing no evidence of injury were removed from three individuals of each selected species. All the leaves were photographed with a digital camera. Leaf area was determined using an image analyzer according to the procedure described by Garnier et al. (2001). After being photographed, two to three the leaf laminas per species were dried in oven at $60{ }^{\circ} \mathrm{C}$ for at least $48 \mathrm{~h}$ to constant weight and then weighed on an analytical balance to determine the dry mass of the leaf. Specific leaf area (SLA) was calculated as the ratio between the leaf area and leaf dry mass [SLA $=$ leaf area $\left(\mathrm{cm}^{2}\right) /$ dry leaf mass $\left.(\mathrm{g})\right]$. The remaining leaves (1-4 per species) were fixed with a formaldehydeglacial acetic acid-ethyl alcohol solution (Ruzin 1999). They were then rinsed with tap water to remove fixative residues and stored in a glycerin-ethyl-alcohol-water solution (1:1:1) until sectioning. Voucher specimens information is given in Additional file 1.

Portions of the middle region of the leaf, including the intercostal area from the midvein to the margin were cut, rinsed and dehydrated in increasing concentrations of tert-butanol (10-100\%) with a Leica automatic tissue processor (TP1020) remaining for $24 \mathrm{~h}$ in each concentration. The tissues were embedded in paraffin (melting point: $56{ }^{\circ} \mathrm{C}$ ) and transverse and paradermal sections $10-12 \mu \mathrm{m}$ in thickness were cut with a Leica rotatory microtome (RM2125). The resulting sections were stained with safranin-fast green (Johansen 1940) and mounted on synthetic resin. In the paradermal sections, the cuticle, guard cell length and epidermal cell shapes were examined. In the transverse sections, the thickness of the following features was measured: the total leaf, mesophyll, palisade parenchyma, spongy parenchyma, cuticle, and height of the abaxial and adaxial epidermis cells. The measurements were obtained through an Olympus microscope BX-51 attached to an image analyzer (Image Pro-plus version 6.1, Media Cybernetics 2006). For each variable, 25 measures were recorded. Other features, such as the number of palisade parenchyma layers or the spongy parenchyma type (open or compact), were also determined. Laminar size classification followed Webb (1959), detecting 6 categories: nanophyll $\left(0.25-2.25 \mathrm{~cm}^{2}\right)$, microphyll $\left(2.25-20.25 \mathrm{~cm}^{2}\right)$, notophyll $\left(20.25-45 \mathrm{~cm}^{2}\right)$, mesophyll (45-182.25 $\left.\mathrm{cm}^{2}\right)$, macrophyll (182.25-1640.25 $\left.\mathrm{cm}^{2}\right)$ and megaphylly $\left(>1640.25 \mathrm{~cm}^{2}\right)$. Sclerophylly index (SI) was calculated following Boeger and Wisniewski (2003) where SI = leaf dry mass $(\mathrm{g}) / 2$ leaf area $\left(\mathrm{cm}^{2}\right)$, considering SI $>0.6$ as sclerophylly and SI $<0.6$ as mesophylly). Stomatal pore area index (SPI) was calculated following Tian et al. (2016) where SPI = stomatal density*stomatal length* $10^{-4}$. Leaf lamina and midvein descriptions followed Dickison (2000) and tribe classification followed Funk et al. (2009).

Characters were square root and $\log 10$-transformed prior to statistical analyses. Pearson and Sperman correlations were calculated between pairs of leaf traits. In addition we produce a principal component analysis (PCA) to evaluate which leaf traits explained the variation in this site. Analyses were performed with R (R Core Team 2015) and SAS (Statistical Analysis System software version 9, SAS Institute 2002). 


\section{Results}

\section{Leaf morphology}

The leaves were simple in all the species. However, 29\% of species, including most of the studied species of the Tageteae tribe, were deeply lobed. Based on the laminar size, most species were classified in four categories: microphyll (29\% of the species), mesophyll (29\%), notophyll (23\%) and macrophyll (13\%). Only two species (Montanoa grandiflora and Tithonia tubiformis) were classified as megaphyll and one species (Tagetes micrantha) as nanophyll leaves. Laminar shape was variable, from ovate, obovate to elliptic. Toothed or untoothed leaf margins were observed. Serrate margins were common and crenate margins were present in some species. Leaf morphological characters by species are given in Additional file 2 .

\section{Epidermis}

On the surface, the abaxial and adaxial epidermises were glabrous in $95 \%$ of the examined species. The remaining $5 \%$ were glandular, tector or pluricellular uniseriate or possessed multiseriate trichomes. Trichomes could be found on one or both leaf surfaces, but they were more frequent on the abaxial surface. The epidermal cell shape of both surfaces was elongated polygonal or isodiametrical polygonal, with straight (Fig. 2a-c) or wavy anticlinal walls (Fig. $2 \mathrm{~d}-\mathrm{f}$ ). Both amphistomatic and hypostomatic leaves were observed. When amphistomatic, the stomata were more abundant on the abaxial surface. The stomata were anomocytic and rarely anisocytic. The average stomatal density was 362 stomata $/ \mathrm{mm}^{2}$, and the average per tribe is given in Table 1.

On the transverse section, the examined species had cuticle thicknesses varying between 0.19 and $1.15 \mu \mathrm{m}$. In $25 \%$ of the species, the cuticle appeared smooth. Cuticular striae (Fig. $3 a-c$ ) were found in greater abundance in cells of the veins and around trichomes. The epidermises were simple in all taxa. Abaxial (7.48-35.79 $\mu \mathrm{m}$ in height) and adaxial (6.22-40.69 $\mu \mathrm{m}$ in height) epidermises were variable in size. The epidermal cells were generally rectangular in shape and rarely square. In some species, the epidermal cells appeared ovoidal in the periclinal walls due to the elevation of the outer periclinal wall. The outer periclinal wall was often thicker than the internal one,
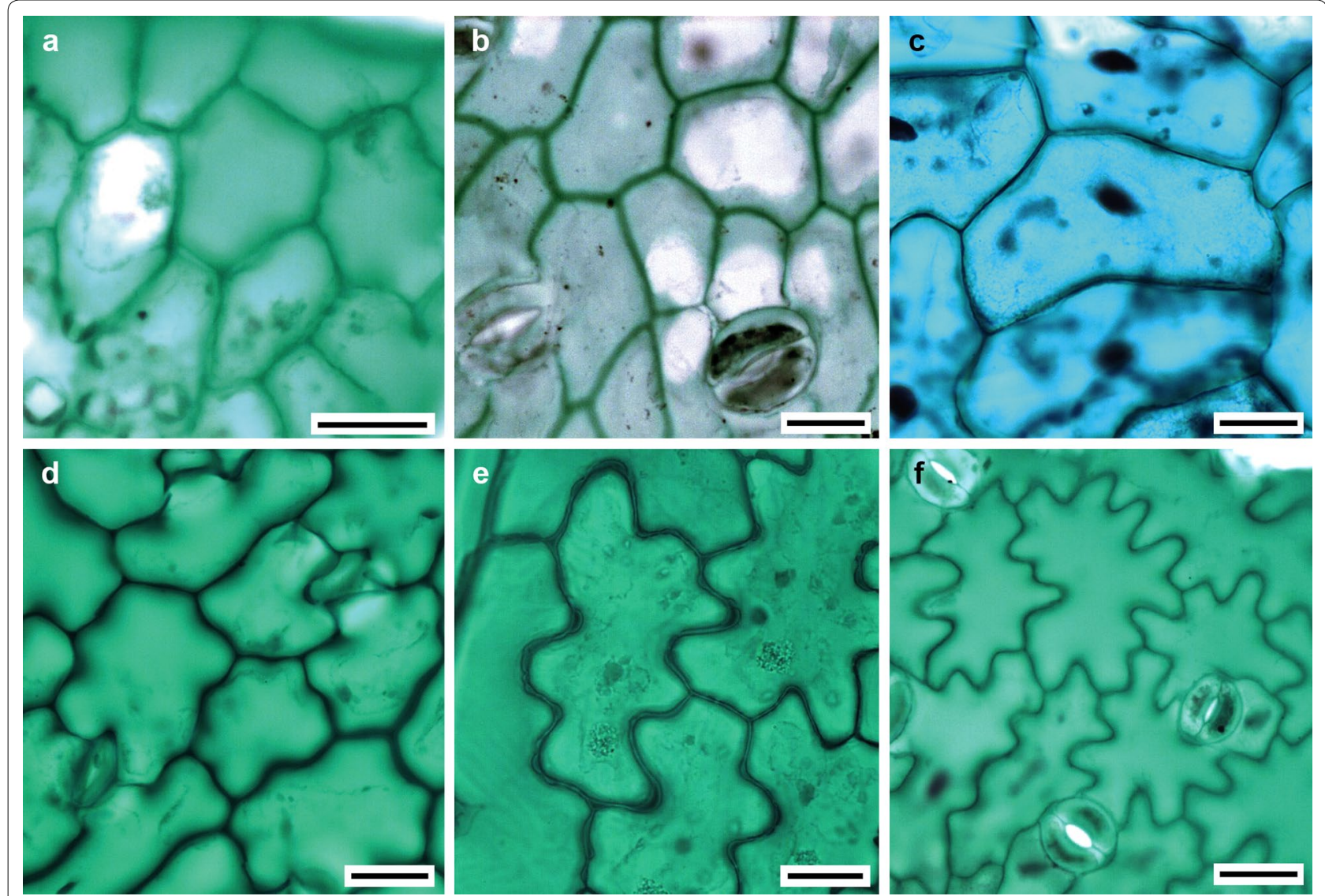

Fig. 2 Epidermal cells forms of Asteraceae. a Conyza canadensis (Tribe Astereae). b Barckleyanthus salicifolius (Senecioneae). c Pittocaulon praecox (Senecioneae). d Pectis prostrata (Tageteae). e Ageratina adenophora (Eupatorieae). f Lactuca serriola (Cichorieae). Bar is $20 \mu \mathrm{m}$ 


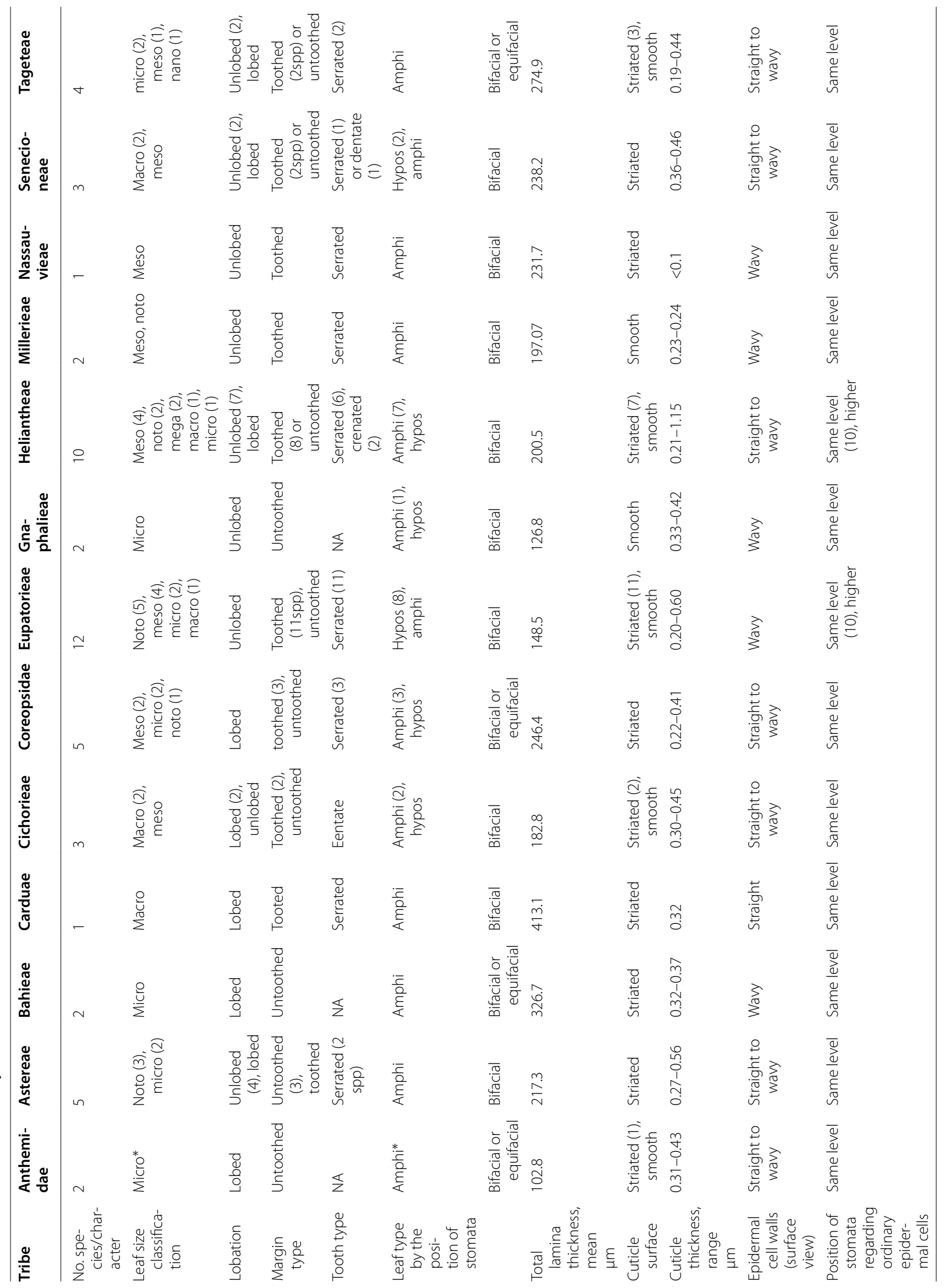




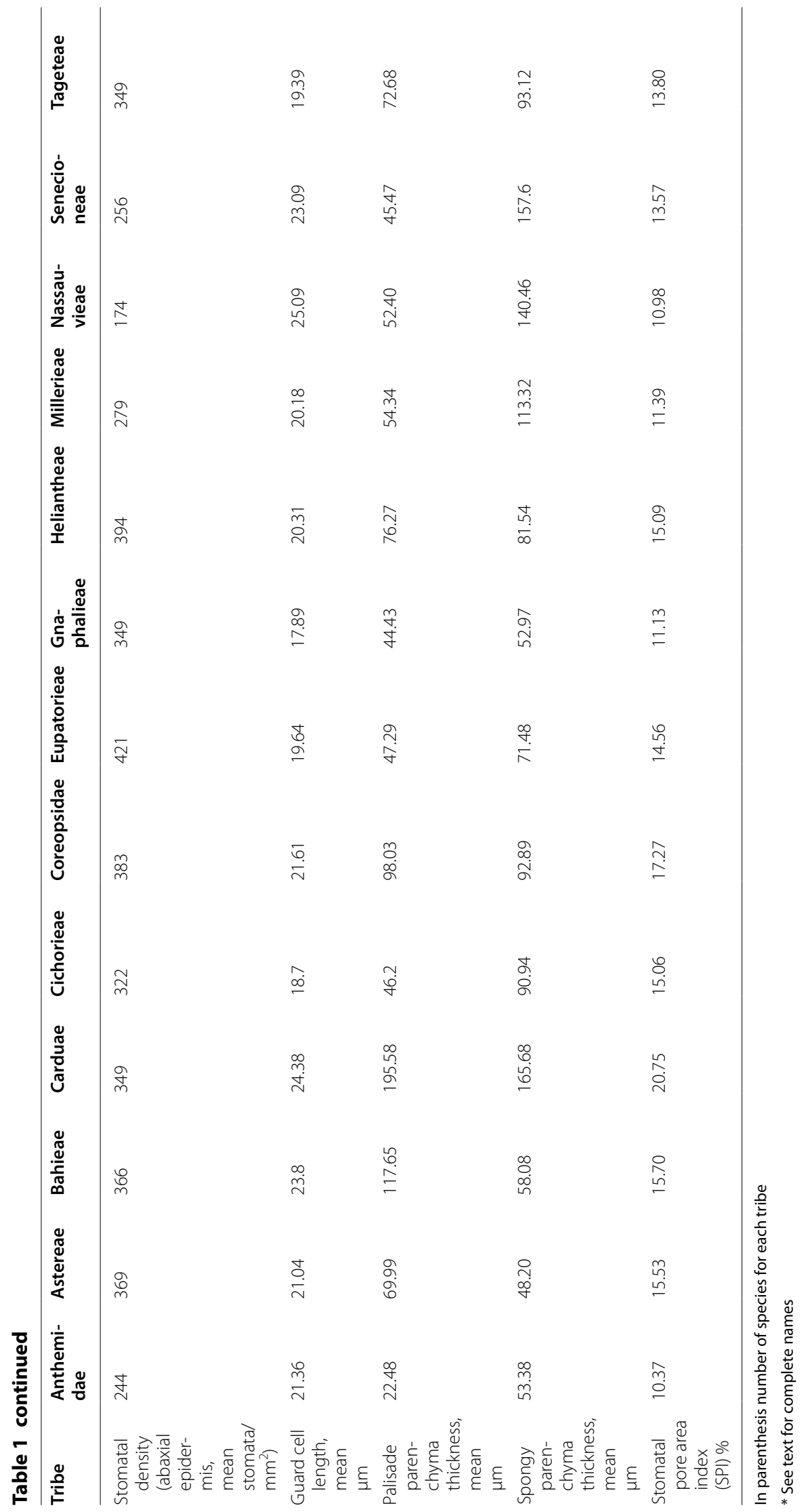




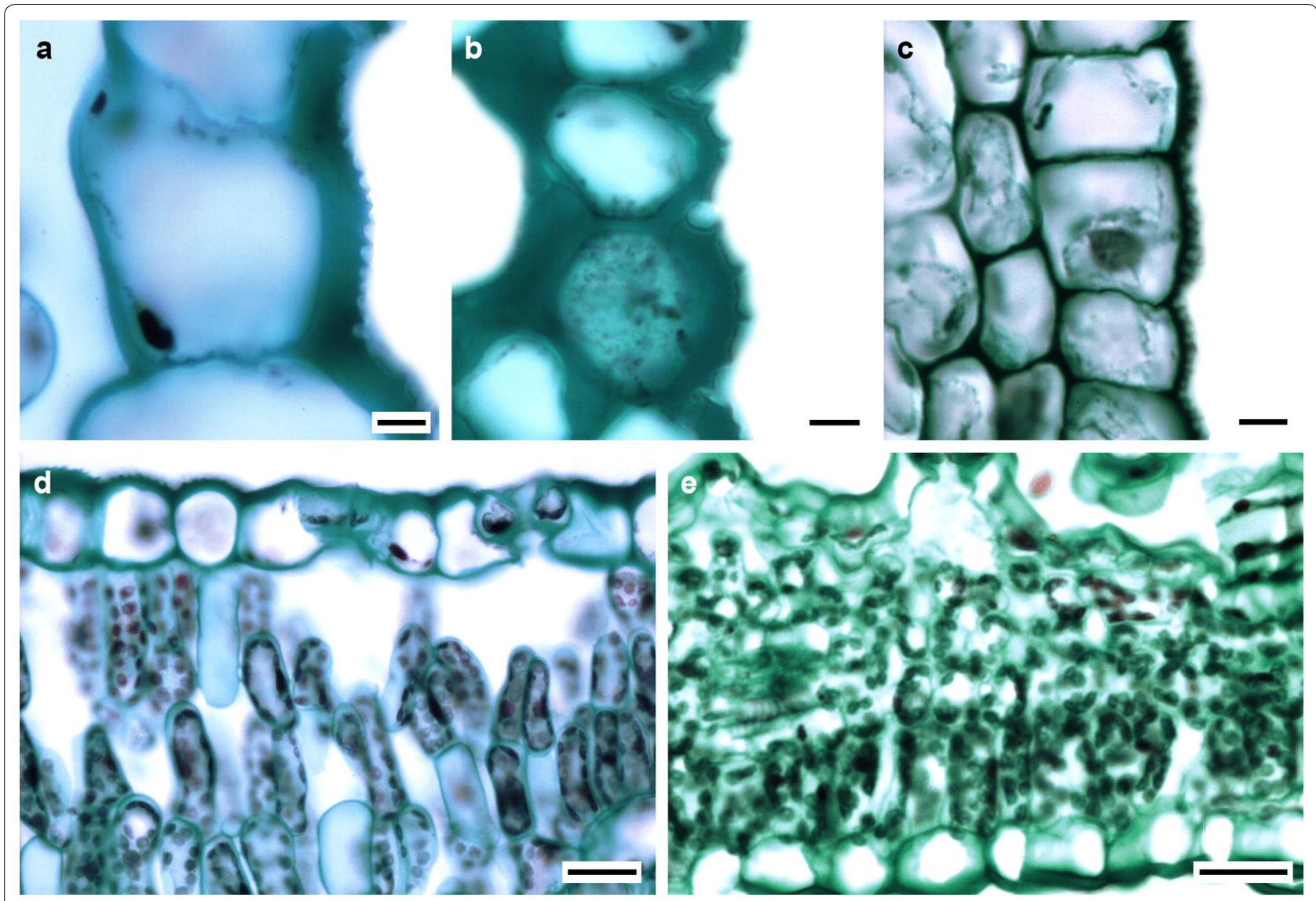

Fig. 3 Cuticular striae and transverse view of stomata of some Asteraceae species. a Baccharis salicifolia (Tribe Astereae). b Ambrosia psilostachya (Heliantheae). c Barckleyanthus salicifolius (Senecioneae). d Baccharis salicifolia (Astereae). e Brickellia secundiflora (Eupatorieae). Bar is $5 \mu \mathrm{m}$ in a-c, $20 \mu \mathrm{m}$ in $\mathbf{d}, \mathbf{e}$

as observed in Dyssodia papposa, Laennecia sophiifolia and Schkuhria pinnata. In some species belonging to the Coreopsideae, Heliantheae and Tageteae tribes, some contents were stained a dark color in the cell lumen of the epidermis. The stomata were located at the same level as other epidermal cells (Fig. 3d) except for some species of the Eupatorieae and Heliantheae tribes, for which they were localized at a higher level than other epidermal ordinary cells (Fig. 3e).

\section{Mesophyll}

A hypodermis was only observed in Pectis prostrata from the Tageteae tribe, where the hypodermis was one cell thick. The mesophyll was dorsiventral in most species and only isofacial in five species (Fig. 4a-d). The palisade parenchyma was formed by one to five cell strata, and, in most cases, it occupied more than half of the total mesophyll thickness. In some species of Astereae and Heliantheae, the palisade parenchyma occupied the most of the mesophyll (Fig. 4). The spongy parenchyma was usually compact in $65 \%$ of the species and loose in the rest.
In some species from Anthemidae, Eupatorieae, Senecioneae and Tageteae tribes, it constituted the whole mesophyll (Fig. 5). There was an aerenchyma in Jaegeria hirta (Millerieae). No mineral contents in the mesophyll cells were observed.

\section{Vascular bundles}

Closed collateral vascular bundles were observed (Figs. 4, 5). In most species, they were surrounded by a sheath of one to three parenchyma layers, which were more conspicuous in species from the Astereae and Tageteae tribes. In the Eupatorieae, Heliantheae, Cichorieae and Senecioneae tribes, sheath extensions towards both surfaces were found (Fig. 5c, d). Secretory canals in some species of Astereae, Eupatorieae and Senecioneae were observed within the sheath (Fig. 4b).

\section{Midvein}

The midvein occupies the central position of the leaf. The epidermis of the midvein in all species was the same as in the lamina, except for Acourtia cordata (Nassauvieae), 

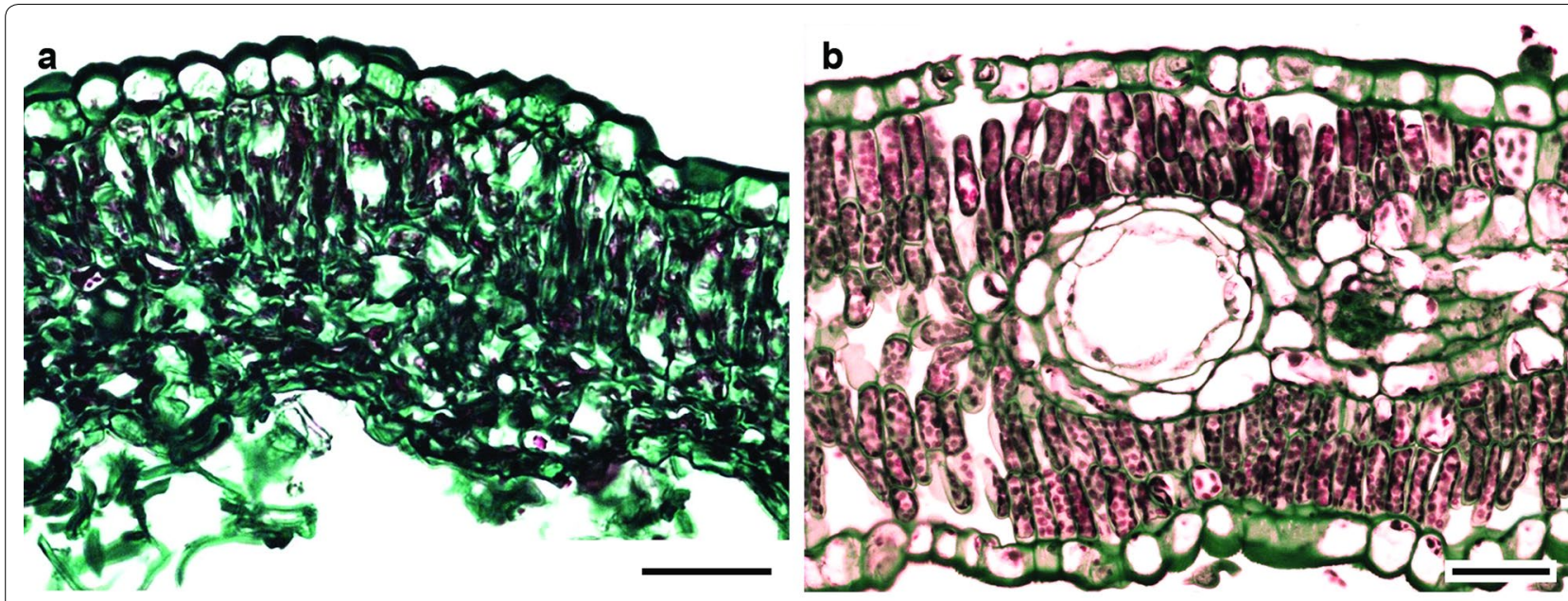

C

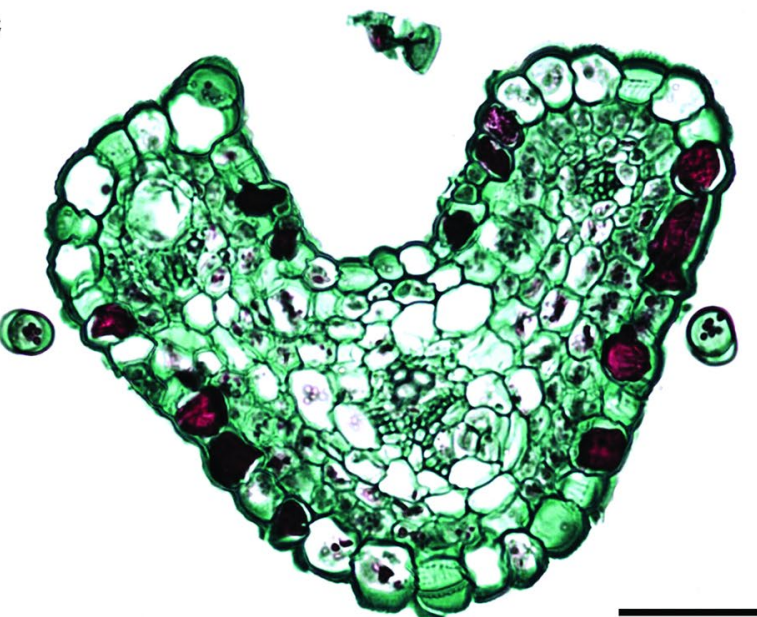

d

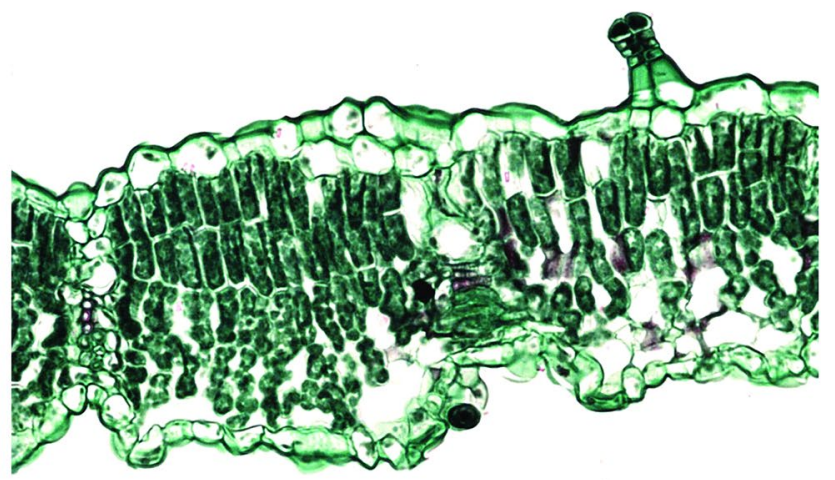

Fig. 4 Variation of mesophyll in Asteraceae. a Artemisia ludoviciana (Tribe Anthemideae). b Baccharis salicifolia (Astereae). c Cosmos bippinatus (Coreopsideae). d Brickellia veronicifolia (Eupatorieae). Bar is $20 \mu \mathrm{m}$

which had a thicker outer epidermal wall. In this area, the mesophyll and the palisade parenchyma were interrupted by angular collenchyma with 9-16 cell layers. The number of bundles composing the midvein was variable (Fig. 6). The vascular tissue generally formed an arch, with parenchyma at both ends of the vascular bundles, except for $A$. cordata, where fibers were observed (Fig. 6a, c-e). No foliar characters were unique to any tribe, and most character states were shared by most tribe members as seen in Table 1.

\section{Statistical analyses}

We found significant correlations between some of the studied characters. For example, there is a negative and significant relationship between the guard cell length and stomatal density (Fig. 7). We also found positive significant correlations between leaf thickness and the thickness of palisade and spongy parenchyma $(\mathrm{r}=0.66, P<0.001)$ and between guard cell length and the thickness of the leaves $(\mathrm{r}=0.43, P=0.003)$, other correlations are shown in Fig. 7. PCA explained in four axes $69 \%$ of the total variance (Table 2). The first axis explains the leaf thickness whereas the second axis explains the positive values for stomatal density and palisade thickness and negative values for guard cell length (Fig. 8).

\section{Discussion}

The foliar anatomy of Asteraceae was variable. In the epidermis, differences were found in the shape of epidermal cells, seen in surface view, and in stomata location, as well as epidermis and cuticle thickness. The cell types constituting the mesophyll were variable as well as their abundance. These observations were consistent with the high foliar variation reported for the family (Anderson and Creech 1975; Metcalfe and Chalk 1979; Ferreira et al. 2002; Freire et al. 2005, 2007; Milán et al. 2006; Adedeji and Jewoola 2008). The striae in the leaf cuticle have been previously observed by other authors (Adedeji and 

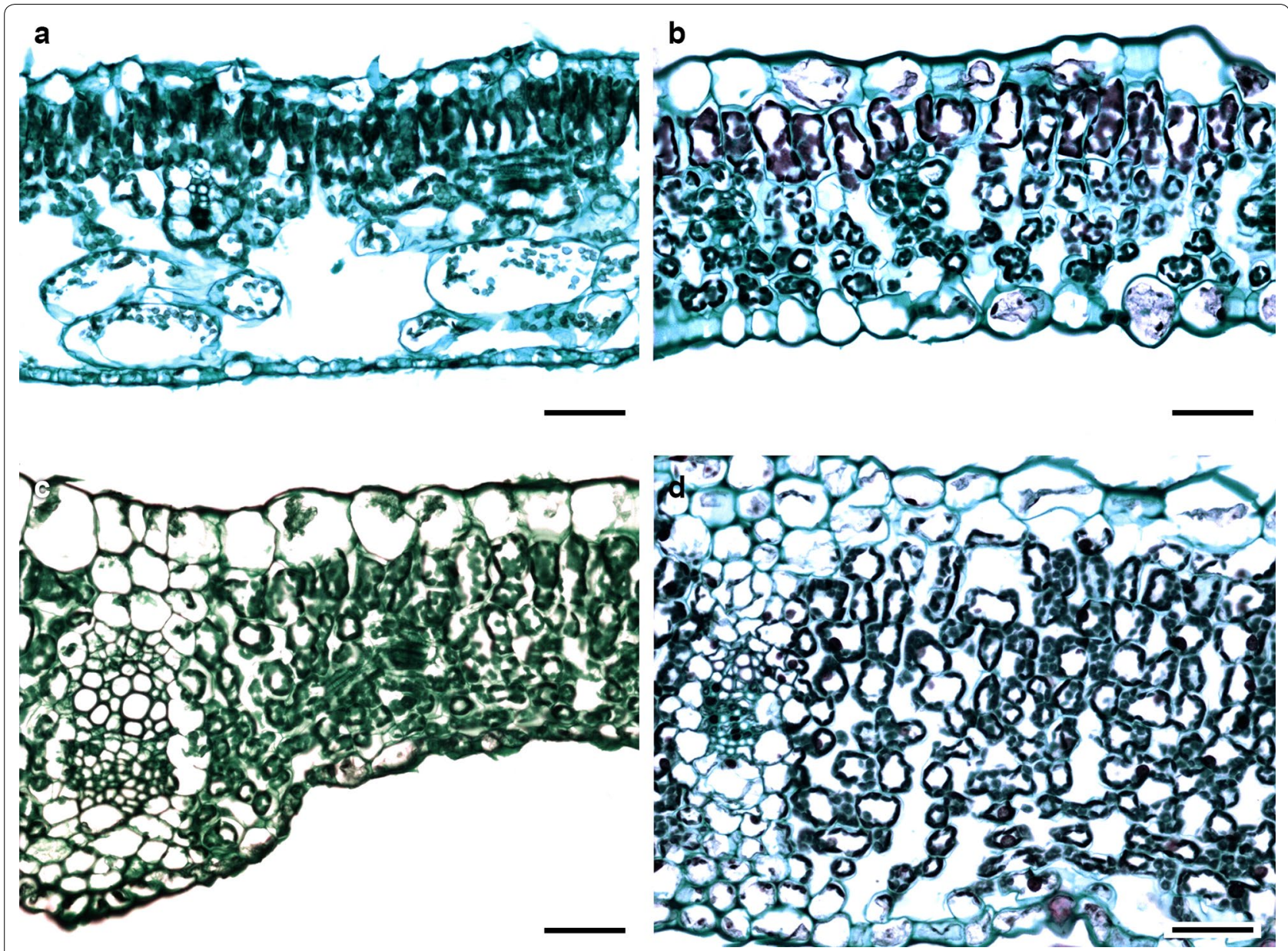

Fig. 5 Variation of mesophyll in Asteraceae. a Jaegeria hirta (Tribe Millerieae). b Montanoa grandiflora (Heliantheae). c Sonchus oleraceus (Cichorieae). d. Pittocaulon praecox (Senecioneae). Bar is $20 \mu \mathrm{m}$

Jewoola 2008), who have suggested that the striae could be used to separate species. The observed stomatal types and the stomata being preferably distributed on the abaxial surface agrees with previous reports for the family in other works (Metcalfe and Chalk 1979; Adedeji and Jewoola 2008).

It was difficult to find a defined anatomical pattern for the family. However, we found that the combination of anatomical features is usually more homogenous within the tribes than the family level. For example, most examined species show bifacial leaves, except for some members of the Bahieae, Coreopsidae and Tageteae tribes, which had equifacial leaves. It should also be stressed that all the members of Astereae had amphistomatic bifacial leaves with striated cuticles, while striae were absent in all members of Gnaphalieae. These observations should be confirmed by examining more Astereae and Gnaphalieae members.
Relationship between the leaves and the habitat

Given that the Asteraceae examined here were found in a habitat with low water availability and poor soils, it was expected that the foliar anatomy would display xerophytic features (Shields 1951; Kramer 1983; Esau 1976; Santos and Ochoa 1990; Fahn and Cutler 1992; Dickison 2000; Cutler et al. 2007). This assertion was not supported by the anatomical features found. The leaves of the Asteraceae studied are better classified as mesomorphic and do not correspond with the vegetation community or the water deficit or poor soils of the volcanic outcrop they leave.

\section{Leaf size}

It was suggested that a small leaf size is a xeromorphic trait because it is correlated with a reduction in transpiration rate (Fahn and Cutler 1992), so we expected to observe leptophyll, nanophyll or microphyll leaves. 


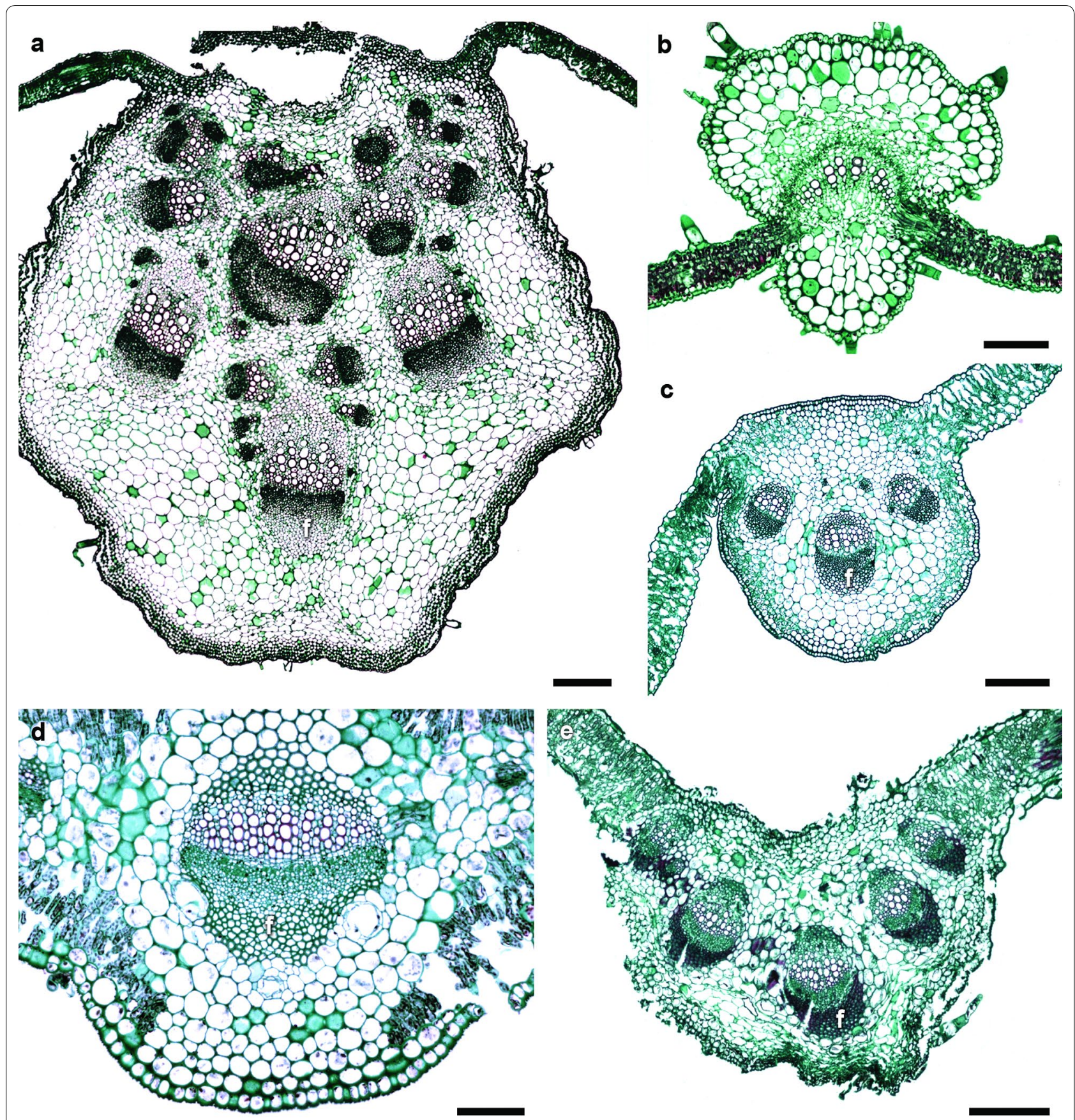

Fig. 6 Midvein of some Asteraceae species. a. Montanoa grandiflora (Tribe Heliantheae). b Ageratina pichinchensis (Eupatorieae). c Picris echioides (Cichorieae). d Baccharis salicifolia (Astereae). e Acourtia cordata (Nassauvieae). Bar is $300 \mu \mathrm{m}$ in a-c, $100 \mu \mathrm{m}$ in d

However, most of the studied species (46\%) have largesized laminae (mesophyll, macrophyll and rarely megaphyll). Twenty-three percent of the studied species had medium-sized laminae (notophyll), and only $31 \%$ of the studied species had small leaves. From the species with larger leaves, $29 \%$ had deeply lobed margins, such as
Dahlia coccinea and Tagetes tenuifolia. Half of the species with the larger leaves were ephemeral herbs that only grow during the rainy season, such as Tithonia tubiformis (megaphyll) and Cirsium vulgare (macrophyll). The other $21 \%$ of the species with larger leaves were deciduous that usually respond rapidly to water stress by producing 

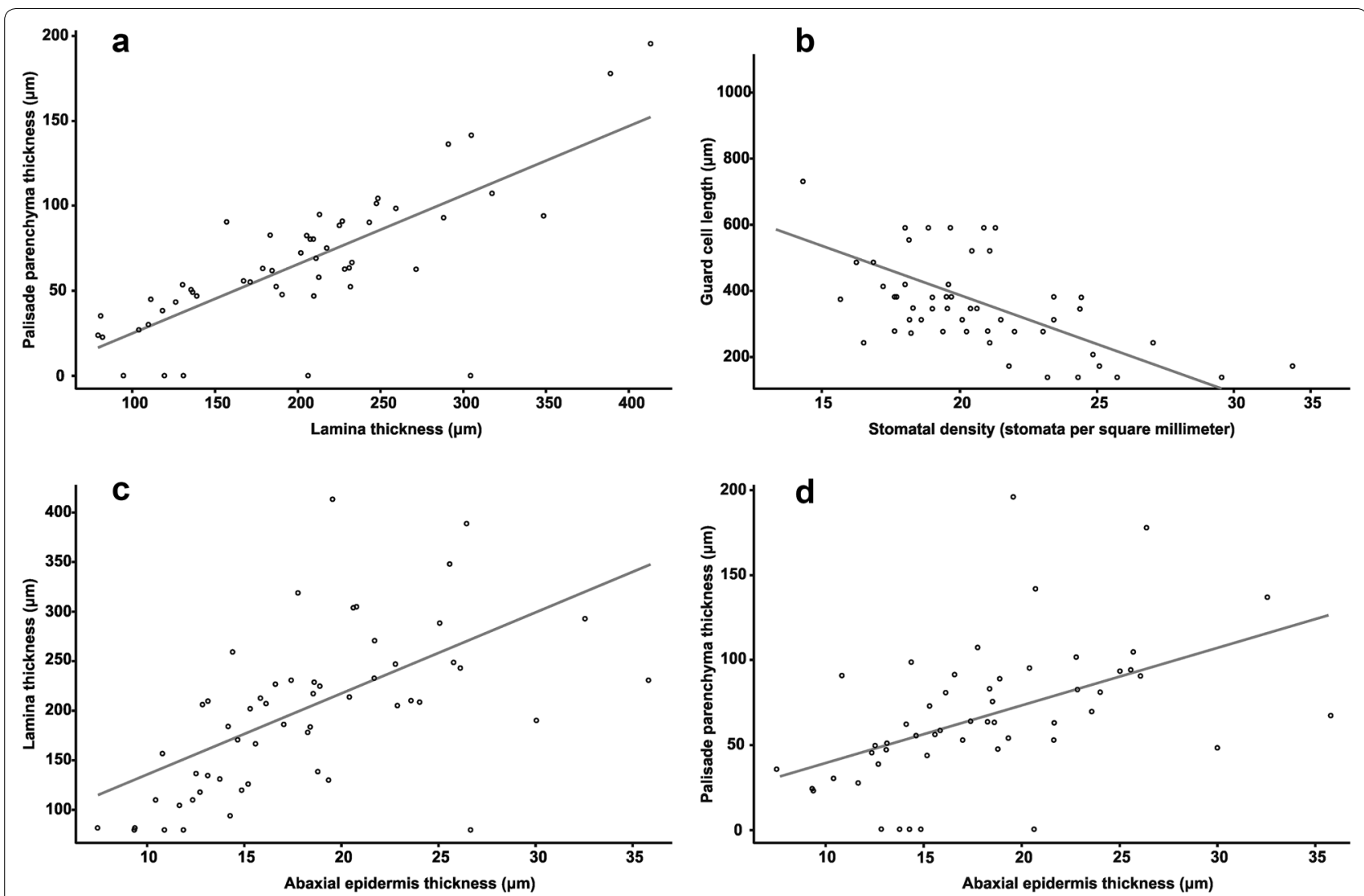

Fig. 7 Correlations among pair of anatomical characters. a Lamina vs palisade parenchyma thickness. b Stomatal density vs guard cell length. c Abaxial epidermis vs lamina thickness. d Abaxial epidermis vs palisade parenchyma thickness

leaves exclusively during the rainy season and losing them when the rain stops, such as Pittocaulon praecox (macrophyll) and Roldana lobata (macrophyll) that is a perennial

Table 2 Eigenvector for principal component analysis for the 11 variables in the first four components analyzed for the leaf traits of the $\mathbf{5 2}$ species of Asteraceae at the REPSA, Mexico

\begin{tabular}{|c|c|c|c|c|}
\hline Characters & Prin 1 & Prin 2 & Prin 3 & Prin 4 \\
\hline Variation explained (\%) & 28.48 & 17.11 & 13.15 & 10.28 \\
\hline Eigenvalue & 3.42 & 2.05 & 1.48 & 1.23 \\
\hline Lamina size & -0.127 & 0.332 & 0.455 & -0.664 \\
\hline Specific leaf area & -0.216 & -0.176 & 0.029 & 0.489 \\
\hline Sclerophyll index & -0.197 & 0.332 & 0.455 & -0.066 \\
\hline Lamina thickness & -0.144 & -0.134 & 0.575 & -0.024 \\
\hline Cuticle thickness & -0.016 & 0.294 & -0.058 & -0.430 \\
\hline Abaxial epidermis height & 0.426 & 0.059 & 0.278 & 0.127 \\
\hline Stomatal density & -0.159 & 0.518 & -0.137 & 0.214 \\
\hline Guard cell length & 0.281 & -0.487 & 0.133 & -0.195 \\
\hline Mesophyll thickness & 0.510 & 0.075 & 0.054 & 0.142 \\
\hline Palisade thickness & 0.216 & 0.455 & 0.067 & 0.204 \\
\hline Spongy thickness & 0.138 & -0.105 & -0.524 & 0.269 \\
\hline
\end{tabular}

herb. Laminar area was expressed as types and this trait was not revealed by our PCA as a variable that contributes to explain the variance in the first four components. The projections of the margin of the lamina (i.e., the lobes and teeth) are interpreted as being related to heat loss morphology (Freire et al. 2005, 2007; Fahn and Cutler 1992; Adedeji and Jewoola 2008; Gil et al. 2012; Schmerler et al. 2012; Redonda-Martínez et al. 2016). Eighty-three percent of the studied species had toothed or lobed margins, which is a common combination in Asteraceae (Bailey and Sinnott 1916; Rojas et al. in review).

\section{Palisade parenchyma}

Gibson (1996) mentioned that non-succulent xerophytes have thicker leaves than mesophytes because they have well developed multi-layered palisade parenchyma. This agrees with our findings because the palisade parenchyma was well developed in most tribes (Table 1), and in some species as Baccharis salicifolia (Astereae) and Lagascea rigida (Heliantheae) the mesophyll is composed exclusively of palisade parenchyma. The palisade thickness was within the range $(94-355 \mu \mathrm{m})$ found in other plant families growing in dry environments (Nevo et al. 


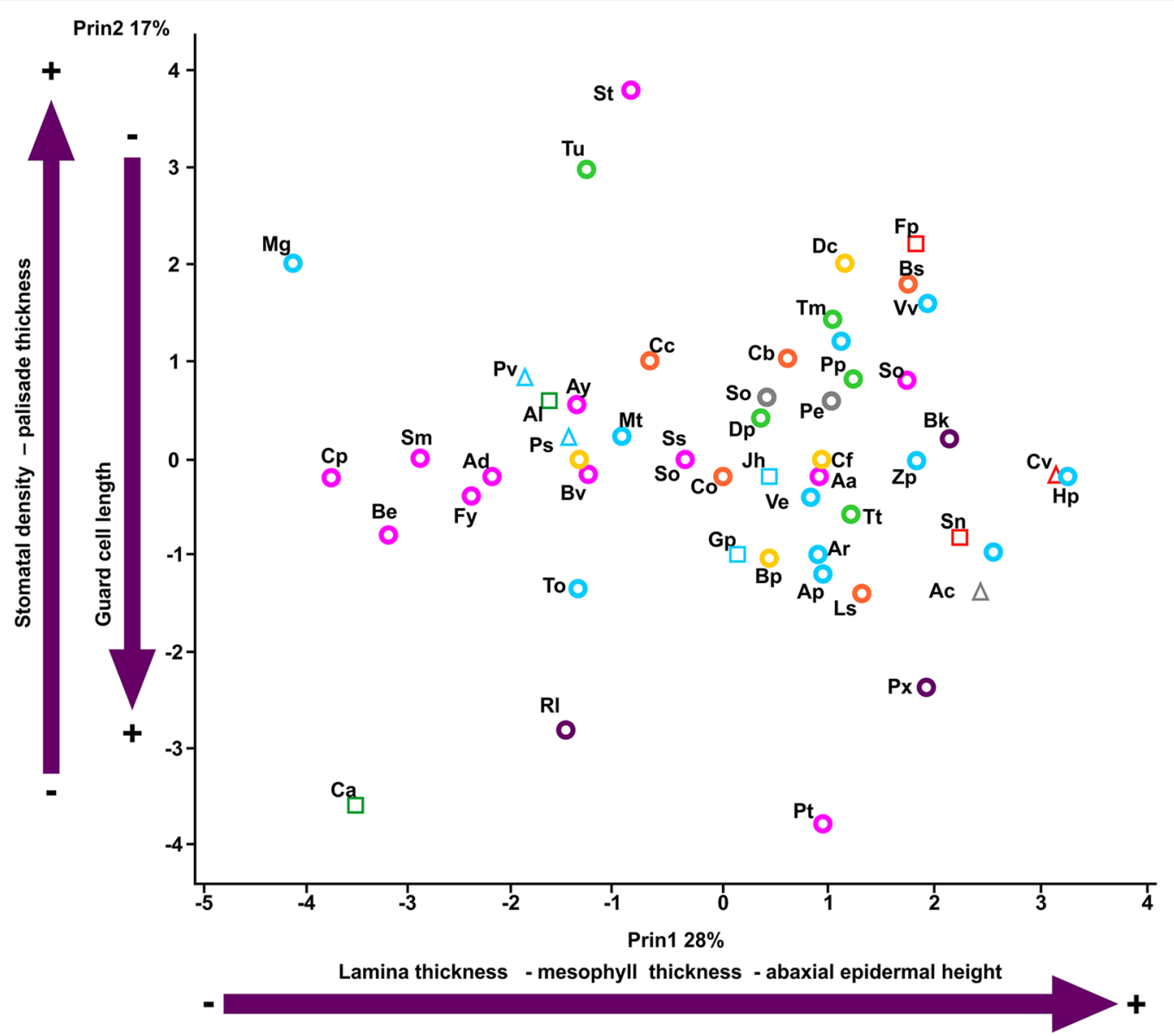

Fig. 8 Biplot of the two principal component axis based on leaf characters plotted for species (letters, see information in Additional file 2) and tribes indicated by colors and symbols

2000; Rotondi et al. 2003; Bacelar et al. 2004; Gratani and Varone 2004). Palisade thickness was one of the variables with high loading to explain the variation found in the species studied, this agrees with the results of Tian et al. (2016) who found that leaf thickness is closely related to palisade and spongy thickness. This close relationship appears to be a strategy together with phenology to be efficient during the rainy season that is short.

\section{SLA, SI and SPI}

Specific leaf area is positive correlated with moisture and nutrient availability (Ackerly et al. 2002) and is mainly determined by leaf density and thickness (Ackerly et al. 2002; Meziane and Shipley 2001). SLA was expected to be low (less than $10 \mathrm{~mm}^{2} / \mathrm{mg}$, Ackerly 2004) because it enhances the photosynthetic rates and the resistance to cell wall collapse under water-stress (Turner 1994; Ackerly 2004). Most of the studied species (78\%) have high values of SLA compared with other species of semiarid environments and are more similar to values found by other authors in temperate and cold forests (15.4$36.3 \mathrm{~mm}^{2} / \mathrm{mg}$, Chen et al. 2011; Tian et al. 2016). SLA have been negatively correlated with leaf lifespan (Shipley et al. 2006; Tian et al. 2016) and this relationship have been explained as the result of increased photosynthetic capacity per unit of leaf dry mass in plants with shorter leaf lifespan. Since the most of the studied species by us are herbs, the high SLA found can be explained by this correlation. Also, compared to the tree species studied by Tian et al. (2016) SLA of the studied species was significantly higher. This can be interpreted as evidence of the correlation between growth form and SLA.

The SI was expected to be higher than 0.6 which is indicative of sclerophyllous leaves. Sclerophylls are typically associated to low nutrient concentration (Turner 1994). However in all the studied species the SI values was lower than expected (Additional file 2). Together these two variables indicate that the studied leaves can be considered mallacophylls (Turner 1994) and mesomorphic. The SPI found for the plants in this study was 
higher than that found for Tian et al. (2016) for some tree species within different ecosystems across China. They discuss that a higher SPI may be an adaptive strategy of leaf stomatal traits that results from higher stomatal conductance and therefore increased photosynthetic capacity which maximize carbon gain during the short growing season (Tian et al. 2016).

\section{Cuticle and epidermis}

We expected to see thick cuticles and a multiseriate epidermis on the leaf surface because those adaptations minimize transpiration rates. However, cuticle thickness was thin compared to other xerophytic plants, which are 2-22 $\mu \mathrm{m}$ thick (Rotondi et al. 2003; Bacelar et al. 2004; Gratani and Varone 2004). Moreover, the thin cuticles found in the REPSA are similar to those reported for species of Ambrosia, Artemisia and Encelia growing in a desert of North America (Gibson 1996). We also expected to see the leaf surface covered with abundant trichomes, but most of the observed species (97\%) were glabrous or had trichomes that were scarcely distributed, except for Pseudognaphalium, Artemisia and Conyza which are herbs growing in open spaces. Most authors have based their taxonomic discussions on trichome morphology (Freire et al. 2005, 2007; Adedeji and Jewoola 2008; Gil et al. 2012; Redonda-Martínez et al. 2016). However in the studied species they were not abundant.

\section{Stomata}

Fahn and Cutler (1992) have hypothesized that amphistomatic leaves may have evolved in response to increasing aridity during the Tertiary period because they increase leaf conductance to $\mathrm{CO}_{2}$. Therefore, amphistomatic leaves favored high maximum leaf conductances and are present in species growing in arid environments (Camargo and Marenco 2011), especially in herbs and shrubs from different environments such as successional forest, deserts or swamps (Mott et al. 1982; Mott and Michaelson 1991). In this study, $60 \%$ of the observed species had amphistomatic leaves and agrees with Mott and Michaelson (1991) findings in Ambrosia cordifolia because most of these species live in full sun during the short rainy season. The stomata in the studied species were at the same level as other epidermal cells. This pattern is different from the one observed in xeromorphic plants, where stomata are usually sunken or protected in crypts. The mean stomatal density found in this study (362 stomata/ $\mathrm{mm}^{2}$ ) was within the range found for other plants growing in arid environments (133-537 stomata/ $\mathrm{mm}^{2}$. Fahn and Cutler 1992; Bacelar et al. 2004; Yiotis et al. 2006; Gil et al. 2012). However, the stomatal densities observed in this environment (Table 1) are lower but not significantly different than those found in mesic environments (462846 stomata $/ \mathrm{mm}^{2}$, Popma et al. 1992; Camargo and Marenco 2011). Wood (1934) suggested that although stomatal density increases with aridity, variations in stomatal density in sclerophyllous forests of South Australia were more related to intra-family characteristics rather than environmental conditions. It is possible that the observed variation in stomatal density has a phylogenetic signal, thus further analysis with a larger Asteraceae sampling growing in different communities is needed to support this assertion. The observed stomatal lengths are similar to the values reported by other authors for Asteraceae growing in arid and temperate environments (16-24 $\mu \mathrm{m}$, Bacelar et al. 2004; Yiotis et al. 2006; Gil et al. 2012). Both stomatal density and length showed a significant negative scaling as found for other species of different families (Hetherington and Woodward 2003; Pearce et al. 2006; Camargo and Marenco 2011) and were important traits that explained part of the variance according to PCA suggesting that they adjust with palisade thickness and spongy parenchyma to maintain efficient photosynthesis.

\section{Dark staining deposits and oils}

It has been suggested that the presence of specialized cell types, such as oil containing cells or tannin cells, may be advantageous in dry environments because they protect the mesophyll cells against excess radiation or against herbivores and help to reduce the evaporation rate by interfering with water movement through the leaves (Fahn and Cutler 1992; Jordaan and Theunissen 1992; Turner 1994). Although we did not perform histochemical tests for tannins, the dark staining deposits that we described may be these contents. Thirty percent of the studied species had oil glands associated to vascular bundles, including B. salicifolia and Barkleyanthus salicifolius. Dark staining deposits were found only in two species (Cosmos parviflorus and D. papposa).

\section{Allometric relationships within the leaf}

The correlation between abaxial epidermis thickness and palisade thickness can be viewed from a functional perspective since it can be interpreted as a relationship between the gas exchange mechanism and the photosynthetic tissue resulting in greater efficiency of the leaf (Shields 1951; Rotondi et al. 2003). Our results of the PCA confirms the close allometric relationships between lamina thickness, palisade and spongy parenchyma and abaxial epidermis found by John et al. (2013) in a sample including various angiosperm families. This relationship has been interpreted as evidence of coordinated changes of the tissues composing the leaf (Brodribb et al. 2013). 
Particularly the correlation between guard cell length and leaf thickness may be showing that the changes in cell size are key to the coordinated variation of leaf size.

\section{Leaves classification}

Some of the studied species showed indicator traits of each of three types of response strategies to water stress and absence of soil. In species of the Eupatorieae (2 spp: Ageratina adenophora and Stevia tomentosa), Tageteae (3 spp: D. papposa, T. micrantha, Pectis prostrata), and Heliantheae (L. rigida) tribes, some foliar features corresponding to the avoidance strategywater loss minimization-were observed. Those characteristics were hypostomatic or bifacial leaves with well developed, many-layers-thick palisade parenchyma, generally striated cuticles, thick epidermises, and vascular bundles surrounded by a well differentiated parenchyma sheath. In accordance with the foliar anatomy some other plant features indicate that these species prefer the avoidance strategy: Eupatorieae species that are generally shrubs or perennial herbs, there are rhizomes allowing them to store water and all leaves from the examined species of Tageteae were lobulate. The tolerance strategy was observed in all the species from the Senecioneae tribe. They showed traits such as leaf abscission during the higher stress season (November-May), mucilage accumulation (in the shoot), and perennation structures that allow regrowth. Some species from the Astereae tribe (4 spp, including Conyza canadensis and L. sophiifolia), and some members of Coreopsidae (e.g. C. parviflorus) and Heliantheae (e.g. Tithonia tubiformis) tribes, showed an escape strategy because they usually developed their life cycle during the rainy season (June-October) and produced seeds before water stress conditions arrived.

Most of the species showed a combination of characters that made their classification difficult. For example, species from the Bahieae and Carduae tribes are annual herbs that grow mainly from June to October; thus, they could be considered escapists. However, these species showed some avoidance features, such as lobulate leaves with striated cuticles and a well-developed palisade parenchyma. This agrees with the asseveration from some authors (Jones 1992; Chaves et al. 2003) about the three strategies not being mutually exclusive but instead we can find a combination of indicator traits of all three strategies within the same plant. The different character combinations for each species could be explained as a result of a fast evolutionary process as proposed by Stebbins (1952) for some members of Cichorieae (Asteraceae).

\section{Conclusions}

The foliar anatomy of Asteraceae was variable, even among members of the same tribe growing in the same locality. If the observed variations were the result of adaptation to a xeric and poor-soil environment, then the observed features would correspond to non-succulent xeromorphic leaves but it was not the case. The majority of the studied species possess mesomorphic leaf features as simple lamina, single-layered epidermis, and soft (mallacophyllous) large-size leaves with high SLA. Although some characters of drought resistance can be observed as for well-developed palisade and parenchyma bundle sheaths. The aforementioned character combination made difficult to classify the species studied within one of the three main response strategies to water stress. We suggest that the occurrence of specific character combinations in each species is due to a very fast evolutionary process involving the growth form, the adaptation to the environment and the phylogeny of the family. A character evolution analysis in an Asteraceae phylogeny including genera endemic to Mexico is needed in order to support this hypothesis (Terrazas, on going research).

The combined study of morphological and anatomical traits and its correlations is important to understand the constraints imposed over the diversity generated by phylogeny and adaptation. For example, although leaf anatomy is not xeromorphic in the studied species, it is advantageous for the species living in the REPSA to have the combination of traits mentioned. Those traits allow them to survive in full sun during the short rainy season having efficient photosynthetic capacity. Assuming that species from the forests around the Xitle colonized the REPSA, it is not surprising that they retained some of their mesic characters and also adapted to the low water environment. There were also species with Neotropical and Nearctic affinities that probably had to modify their leaves to colonize new environments. These species probably retained the capacity to adapt to dry environments, and that is one of the reasons for their success. It is known that in ecological succession, pioneer species need to have low nutritional requirements and efficient metabolisms to survive. The invasiveness of Asteraceae species is probably related to their capacity to grow in this poor-soil environment.

\section{Additional files}

Additional file 1. Voucher information for species used in this study. All specimens deposited in Herbario Nacional de México (MEXU), Instituto de Biología, Universidad Nacional Autónoma de México.

Additional file 2. Leaf characters by species in Asteraceae. 


\section{Abbreviations}

REPSA: Pedregal de San Ángel Ecological Reserve; UNAM: National Autonomous University of Mexico; SLA: specific leaf area; SI: sclerophylly index; SPI: stomatal pore area index; PCA: principal component analysis.

\section{Authors' contributions}

PR and TT designed the study, PR carried out the laboratory work, analyzed the data and drafted the manuscript. TT analyzed the data, revised and corrected the manuscript. JLV approved the manuscript. All authors read and approved the final manuscript.

\section{Author details}

${ }^{1}$ Departamento de Botánica, Instituto de Biología, Universidad Nacional Autónoma de México, Apartado Postal 70-367, 04510 Mexico City, Mexico.

${ }^{2}$ Coordinación del Posgrado en Ciencias Biológicas, Circuito de Posgrados Ciudad Universitaria, Coyoacán, 04510 Mexico City, Mexico.

\section{Acknowledgements}

This study is part of the requirements for PR to obtain the Doctor of Science degree from the Posgrado en Ciencias Biológicas UNAM (PCB). We thank Oscar Hinojosa for his help in the collection and identification of the plants, Dalia Grego for her support in many aspects of the laboratory work, Enrique Ortiz for doing the climograph and the map and Itzi Fragoso for her help with map edition. We appreciate the comments of the reviewers.

\section{Competing interests}

The authors declare that they have no competing interests.

\section{Availability of data and materials}

The dataset supporting the conclusions of this article is included within the article and its Additional files 1, 2 .

\section{Funding}

PR thanks CONACYT for a scholarship (288322). JLV thanks the UNAM-DGAPAPAPIIT (IN213916) program for financial support to acquire material and collect the plants.

Received: 30 September 2016 Accepted: 16 February 2017

Published online: 23 February 2017

\section{References}

Ackerly DD (2004) Adaptation, niche conservatism and convergence: comparative studies of leaf evolution in the Californian chaparral. Amer Nat 163:654-671

Ackerly DD, Knight CA, Weiss SB, Barton K, Starmer KP (2002) Leaf size, specific leaf area and microhabitat distribution of chaparral woody plants: contrasting patterns in species level and community level analyses. Oecologia 130:449-457

Adedeji O, Jewoola OA (2008) Importance of leaf epidermal characters in the Asteraceae family. Not Bot Horti Agrobot Cluj Napoca 36:7-16

Anderson LC, Creech JB (1975) Comparative leaf anatomy of Solidago and related Asteraceae. Am J Bot 62:486-493

Bacelar EA, Correia CM, Moutinho-Pereira JM, Goncalves BC, Lopes Jl, TorresPereria JMG (2004) Sclerophylly and leaf anatomical traits of five fieldgrown olive cultivars growing under drought conditions. Tree Physiol 24:233-239

Bailey IW, Sinnott EW (1916) The climatic distribution of certain types of angiosperms leaves. Am J Bot 3:24-39

Boeger MRT, Wisniewski C (2003) Comparacao da morfologia foliar de espécies arbóreas de tres estádios sucessionais distintos de floresta ombrófila densa (Floresta Atlántica) no Sul do Brasil. Rev Brasil Bot 26:61-72

Brodribb TJ, Jordan GJ, Carpenter RJ (2013) Unified changes in cell size permit coordinated leaf evolution. New Phytol 199:559-570

Camargo MAB, Marenco RA (2011) Density, size and distribution of stomata in 35 rainforest tree species in Central Amazonia. Acta Amazonica 41:205-212

Castillo-Argüero S, Montes-Cartas G, Romero-Romero MA, Martínez-Orea Y, Guadarrama-Chávez P, Sánchez-Gallén I, Núñez-Castillo O (2004)
Dinámica y conservación de la flora del matorral xerófilo de la Reserva Ecológica del Pedregal de San Angel (D.F.) México. Bol Soc Bot México 74:51-75

Castillo-Argüero S, Martínez-Orea Y, Romero-Romero MA, GuadarramaChávez P, Núñez-Castillo O, Sánchez-Gallén I, Meave JA (2007) La reserva ecológica del Pedregal de San Ángel: Aspectos florísticos y ecológicos. México: Secretaria Ejecutiva de la Reserva Ecológica del Pedregal de San Ángel de Ciudad Universitaria, Universidad Nacional Autónoma de México

Castro MM, Leitão-Filho HF, Monteiro WR (1997) Utilização de estruturas secretoras na identificação dos gêneros de Asteraceae de uma vegetação de cerrado. Rev Brasil Bot 20:163-174

Céspedes CLA (2010) Riqueza florística de Asteraceae en los fragmentos de vegetación de la Reserva Ecológica del Pedregal de San Ángel, México D.F. M. Sc. Thesis. México: Facultad de Ciencias, Universidad Nacional Autónoma de México

Chaves MM, Maroco JP, Pereira JS (2003) Understanding plant responses to drought-from genes to the whole plant. Funct Plant Biol 30:239-264

Chen FS, Niklas KJ, Zeng DH (2011) Important foliar traits depend on speciesgrouping: analysis of a remnant temperate forest at the Keerqin Sandy Lands, China. Plant Soil 340:337-345

Cutler DF, Botha T, Stevenson DW (2007) Plant anatomy: an applied approach. Blackwell Publishing, Massachusetts

Delbón NM, Cosa T, Dottori N, Stiefkens L (2007) Análisis comparativo de los caracteres epidérmicos en Flourensia campestris y F. oolepis (Asteraceae). Bol Soc Argent Bot 42:245-250

Dickison WC (2000) Integrative plant anatomy. Academic Press, San Diego

Esau K (1976) Anatomía vegetal. Ediciones Omega, España. English edition: Esau K (1976) Plant anatomy (trans: Pons J). John Willey \& Sons Inc., New York

Fahn A, Cutler DF (1992) Xerophytes. Gebrüder Borntraege, Berlin

Fang Y, Xiong L (2015) General mechanisms of drought response and their application in drought resistance improvement in plants. Cell Mol Life Sci 72(673):689

Ferreira JL, De Oliveira FV (1989) Identificaçao de Sonchus oleraceus L. (serralha): Principais características estruturais e químicas. Rev Bras Farmacogn 2/4:67-77

Ferreira EA, Procópio SO, Silva EAM, Silva AA, Rufino RJN (2002) Estudos anatômicos de folhas de espécies de plantas daninhas II. Planta Daninha 20:327-335

Fonseca CR, Overton JM, Collins B, Westoby M (2000) Shifts in trait-combinations along rainfall and phosphorus gradients. J Ecol 88:954-977

Freire S, Arambarri AM, Bayón N, Sancho G, Urtubey E, Monti C, Novoa MC, Colares MN (2005) Epidermal characteristics of toxic plants for cattle from the Salado river basin (Buenos Aires, Argentina). Bol Soc Argent Bot 40:241-281

Freire S, Urtubey E, Guiliano DA (2007) Epidermal characters of Baccharis (Asteraceae) species uses in traditional medicine. Caldasia 29:23-38

Funk VA, Susanna A, Stuessy TF, Robinson H (2009) Classification of Compositae. In: Funk VA, Susanna A, Stuessy TF, Bayer RJ (eds) Systematics, evolution, and biogeography of Compositae. Sheridan Books Inc, Ann Arbor

Garnier E, Shipley B, Roumet C, Laurent G (2001) A standarized protocol for the determination of specific leaf area and leaf dry matter content. Func Ecol 15:688-695

Gibson AC (1996) Structure-function relations of warm desert plants. Springer Verlag, Berlin

Gil SP, Seisdedos L, Reyna ME, Cerana MM (2012) Epidermis foliar de tres especies de asteráceas nativas de Argentina con potencial ornamental. Phyton (B. Aires) 81:205-210

Gratani L, Varone L (2004) Leaf key traits of Erica arborea L., Erica multiflora L. and Rosmarinus officinalis L. co-occurring in the Mediterranean maquis. Flora 199:58-69

Hetherington AM, Woodward FI (2003) The role of stomata in sensing and driving environmental change. Nature 424:901-908

Horn JW, Fisher JB, Tomlinson PB, Lewis CE, Laubengayer K (2009) Evolution of lamina anatomy in the palm family (Arecaceae). Am J Bot 96:1462-1486

Johansen DA (1940) Plant microtechnique. MacGraw Hill, New York

John GP, Scoffoni C, Sack L (2013) Allometry of cells and tissues within leaves. Am J Bot 100:1936-1948

Jones HG (1992) Plants and microclimate. Cambridge University Press, Cambridge 
Jordaan A, Theunissen JD (1992) Phenolic deposits and tannin in the leaves of five xerophytic species from southern Africa. Bot Bull Academia Sinica 33:55-61

Kramer PJ (1983) Water relations of plants. Academic Press, New York

Lot A, Cano-Santana Z (2009) Biodiversidad del ecosistema del pedregal de San Ángel. Universidad Nacional Autónoma de México, México

Luckow M (2002) Anatomical features of the leaves in the Dichrostachys group (Leguminosae: Mimosoideae) and their utility for Phylogenetic studies. Syst Bot 27:29-40

Luque R, De Menezes NL, Semir J (1999) Anatomía foliar de Lychnophora Mart. (Vernonieae: Asteraceae). Plantula 2:141-152

Metcalfe C, Chalk L (1979) Anatomy of the dicotyledons, 2nd edn. Oxford University Press, New York

Meziane D, Shipley B (2001) Direct and indirect relationships between specific leaf area, leaf nitrogen and leaf gas exchange. Effects of irradiance and nutrient supply. Ann Bot 88:915-927

Milán P, Hayashi AH, Appezzato-da-Glóra B (2006) Comparative leaf morphology and anatomy of three Asteraceae species. Braz Arch Biol Technol 49:135-144

Morrone JJ (2006) Biogeographic areas and transition zones of Latin America and the Caribbean islands based on panbiogeographic and cladistic analyses of the entomofauna. Annu Rev Entomol 51:467-494

Mott KA, Michaelson O (1991) Amphistomy as an adaptation to high lightintensity in Ambrosia cordifolia (Compositae). Am J Bot 78:76-79

Mott KA, Gibson AC, I'Leary JW (1982) The adaptive significance of amphistomatic leaves. Plant Cell Environ 5:455-460

Nevo E, Pavlíek T, Beharav A, Bolshakova MA, Martyn Gl, MusatenkoLI Sytnik KM (2000) Drought and light anatomical adaptive leaf strategies in three woody species caused by microclimatic selection at "Evolution Canyon", Israel. Israel J Plant Sci 48:33-46

Ordoñez JC, Van Bodegom PM, Witte JPM, Wright IJ, Reich PB, Aerts R (2009) A global study of relationships between leaf traits, climate and soil measures of nutrient fertility. Global Ecol Biogeogr 18:137-149

Pearce DW, Millard S, Bray DF, Rood SB (2006) Stomatal characteristics of riparian poplar species in a semi-arid environment. Tree Physiol 26:211-218

Popma J, Bongers F, Werger MJA (1992) Gap-dependence and leaf characteristics of trees in a tropical lowland rain forest in Mexico. Oikos 63:207-214

R Core Team (2015) R: A language and environment for statistical computing. R Foundation for Statistical Computing, Vienna, Austria. https://www.Rproject.org/

Ragonese AM (1988) Canales secretores en los órganos vegetativos de Eupatorium inulaefolium H.B.K. (Compositae). Acta Farm Bonaer 7:161-168

Redonda-Martínez R, Villaseñor JL, Terrazas T (2016) Trichome diversity in the subtribe Leiboldiinae (Vernonieae, Asteraceae). J Torrey Bot Soc 143:298-310

Rojas A, Terrazas T, Villaseñor JL (in review). Foliar architecture in members of Senecioneae (Asteraceae). Rev Mex Biodivers

Rotondi A, Rossi F, Asunis C, Cesaraccio C (2003) Leaf xeromorphic adaptations of some plants of a coastal Mediterranean macchia ecosystem. J Mediterr Ecol 4:25-35
Ruzin ES (1999) Plant microtechnique and microscopy. Oxford University Press, New York

Rzedowski J (1998) Diversidad y orígenes de la flora fanerogámica de México. In: Ramamoorthy TP, Bye R, Lot A, Fa J (eds) Diversidad biológica de México: Orígenes y distribución. Instituto de Biología, Universidad Nacional Autónoma de México, México, D.F

Rzedowski J (2006) Vegetación de México. 1st digital edition. Comisión Nacional para el Conocimiento y Uso de la Biodiversidad, México

Rzedowski GC, Rzedowski J (2005) Flora fanerogámica del Valle de México. 2nd ed., 1st reimp., Instituto de Ecología, A.C. y Comisión Nacional para el Conocimiento y Uso de la Biodiversidad, Pátzcuaro

Santos MS, Ochoa N (1990) Adaptación de las plantas al déficit hídrico. Ciencia 41:333-344

Schmerler SB, Clement WL, Beaulieu JM, Chatelet DS, Sack L, Donoghue MJ, Edwards EJ (2012) Evolution of leaf form correlates with tropicaltemperate transitions in Viburnum (Adoxaceae). Proc R Soc Lond B Bio 279:3905-3913

Shields LM (1951) Leaf xeromorphy in dicotyledon species from a gypsum sand deposit. Am J Bot 38:175-190

Shipley B, Lechowicz MJ, Wright I, Reich PB (2006) Fundamental trade-offs generating the worldwide leaf economics spectrum. Ecology 87:535-541

Siebe C (2000) Age and archaeological implications of Xitle volcano, southwestern Basin of Mexico-City. J Volcanol Geotherm Res 104:45-64

Soto-Trejo F, Palomino G, Villaseñor JL (2011) Números cromosómicos de Asteraceae de la Reserva Ecológica del Pedregal de San Ángel (REPSA), México, Distrito Federal. Rev Mex Biodivers 82:383-393

Stebbins GL (1952) Aridity as a stimulus to plant evolution. Amer Nat 86:33-44

Tian M, Yu G, He N, Hou J (2016) Leaf morphological and anatomical traits from tropical to temperate coniferous forests: mechanisms and influencing factors. Sci Rep 6:19703

Turner IM (1994) Sclerophylly: primary protective? Funct Ecol 8:669-675

Valladares F, Vilagrosa A, Peñuelas J, Ogaya R, Camarero JJ, Corcuera L, Sisó S, Gil-Pelegrín E (2004) Estrés hídrico: ecofisiología y escalas de la sequía. In: Valladares $F$ (ed) Ecología del bosque mediterráneo en un mundo cambiante. Ministerio de Medio Ambiente, EGRAF, S. A, Madrid

Webb $L J$ (1959) A physiognomic classification of Australian rain forests. J Ecol 47:551-570

Wood JG (1934) The physiology of xerophytism in Australian plants. The stomatal frequencies, transpiration and osmotic pressures of sclerophyll and tomentose-succulent leaved plants. J Ecol 22:69-87

Wright IJ, Westoby M, Reich PB (2002) Convergence towards higher leaf mass per area in dry and nutrient poor habitats has different consequences for leaf life span. J Ecol 90:534-543

Yiotis C, Manetas Y, Psaras GK (2006) Leaf and green stem anatomy of the drought deciduous Mediterranean shrub Calicome villosa (Poiret) Link. (Leguminosae). Flora 201:102-107

\section{Submit your manuscript to a SpringerOpen ${ }^{\odot}$ journal and benefit from:}

- Convenient online submission

- Rigorous peer review

- Immediate publication on acceptance

- Open access: articles freely available online

- High visibility within the field

- Retaining the copyright to your article

Submit your next manuscript at springeropen.com 